\title{
Emergence of Small Invertebrates in the Shallow Subtidal Zone: Investigations in a Subtropical Sea at Iriomote-jima in the Ryukyu Islands, Japan
}

\author{
Masayuki Saigusa and Kazushi Oishi \\ Department of Biology, Faculty of Science, Okayama University, \\ Tsushima 2-1-1 (General Education Buildings), Okayama 700-8530, Japan
}

\begin{abstract}
Many invertebrates inhabit the shallow subtidal zone in subtropical regions, and some of them also emerge at times into the water column. To detect any synchrony of their emergence patterns with the day/night or tidal cycle, and to monitor their abundance in the surface and bottom waters, small invertebrates were collected continuously for one month at Iriomote-jima in the Ryukyu Islands, Japan. Two pumps were set to collect surface and bottom water, respectively. The daily patterns of emergence in 24 major taxa, mostly crustaceans, were analyzed by visual inspection and statistical methods. A notable feature was a clear nocturnal pattern in all the taxa except Corycaeus sp.; however, the nocturnal pattern varied among taxa with regard to its strength and the influence of the tidal cycle upon it. The emergence patterns of each taxon were much the same between the surface and bottom. Some animals (e.g. Labidocera pavo and Lucifer hanseni) were more abundant in the bottom water, but other animals (e.g. crab zoeas comprising several species) in the surface water. Almost all the animals collected by the pumps were also collected from the bottom substrate in the daytime. Therefore, absence of these invertebrates by day from pump samples does not imply their escape from the area where the pumps were installed, but merely that by day they hide within the bottom substrate or just above it, where very few specimens could be collected even by the bottom pump. Dispersing or swimming into the water column at night, they could then be collected by both pumps. 'Daily emergence/dispersal' may be a better term than 'daily vertical migration' for this behavior pattern in subtropical marine invertebrates. Furthermore, because of similar patterns of periodic activity, the distinction between 'benthos' and 'plankton' is blurred for small subtropical invertebrates.
\end{abstract}

Key words: bottom substrate, emergence/dispersion, nocturnal activity, small invertebrates (plankton and benthos), sublittoral zone, subtropical seas

\section{INTRODUCTION}

Daily (= diel) vertical migration that occurs with a 24 $\mathrm{hr}$ periodicity is one of the most characteristic behavior patterns in marine and lacustrine plankton. Each species has its own preferred range of migration, and this

Received January 11, 1999: Accepted September 20, 1999 varies with not only season and geographical location, but also the life stage and sex of an individual (Lalli \& Parsons 1993). The most common pattern is a nocturnal migration that is characterized by an ascent at night and a descent in the daytime (Gauld 1953; Zaret \& Suffern 1976; Forward 1988; Bollens et al. 1994).

Information is scarce on daily vertical migrations of animals inhabiting shallow sublittoral environments near the shore. Our field investigations carried out in the Inland Sea of Japan suggested that copepods move up and down in the water column over a $24 \mathrm{~h}$ period 
(Oishi \& Saigusa 1999). However, in that study, the sampling of surface and bottom waters was done on different days and in different seasons. To confirm daily vertical movement in a shallow subtidal environment, both bottom and surface samples should be collected at the same time. Furthermore, many invertebrates belong to the shallow subtidal benthos. It is not fully understood whether they also make a daily vertical migration as zooplankton do.

To elucidate these features we designed a method to monitor the abundance of near-shore invertebrates with a pair of impeller pumps; one was placed near the surface, and the other near the bottom. If the animals undertake a daily vertical migration even in the shallow subtidal zone, many more animals should be collected in the bottom water than in the surface water by day, and vice versa at night. On the other hand, if the animals are found only at one level or the other throughout the day, or are only collected either in the daytime or at night, we must consider the possibility of activity other

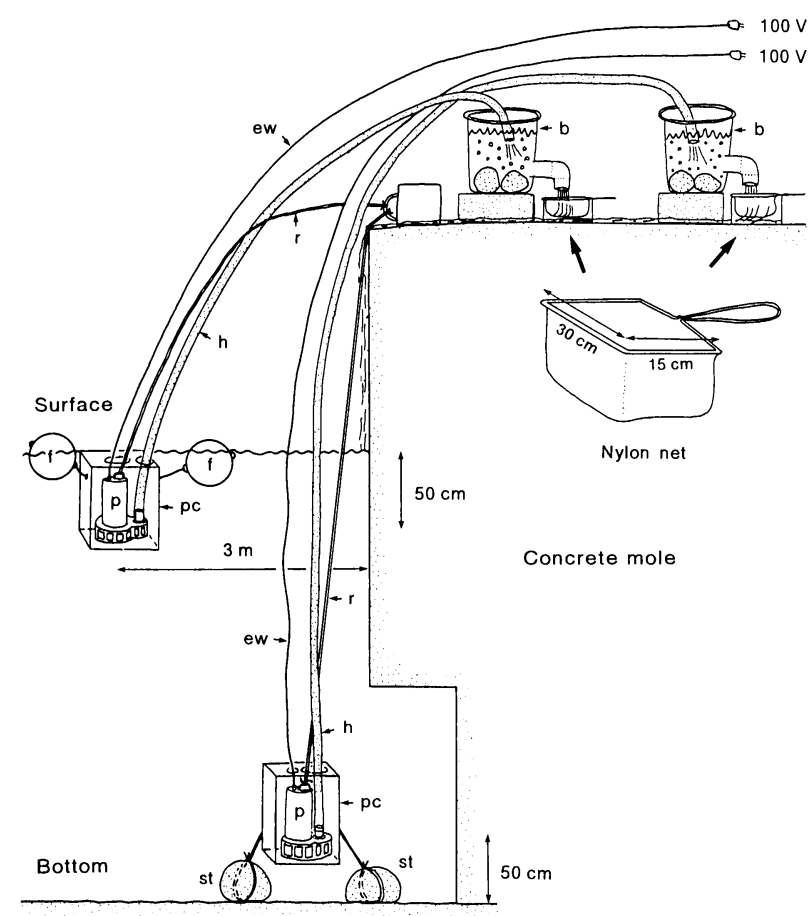

Fig. 1. Method for sampling small sublittoral invertebrates at Iriomote-jima. b: plastic bucket to weaken flow of seawater, ew: electric wire, f: float, h: hose to pump up seawater, p: impeller pump, pc: plastic cover with $1.0 \times$ $6.5 \mathrm{~cm}$ holes to prevent large animals from entering pump, r: rope, st: stone. Small invertebrates were trapped by the nylon nets, collected at intervals of $30 \mathrm{~min}$, and fixed immediately. than a daily vertical migration.

Here we report on small invertebrates collected by this two-pump system at Iriomote-jima, Okinawa Prefecture, Japan. This site was chosen for comparison with the invertebrates in a temperate environment (Oishi \& Saigusa 1999). Among the many species collected by the pumps, the emergence patterns of 24 major taxa, mostly crustaceans, were examined in relation to their synchrony with day/night and tidal cycles, and with regard to their abundance in the surface and bottom waters.

\section{MATERIALS AND METHODS}

\section{Study site and environment}

Invertebrate sampling was carried out from 17 April to 11 May 1998 at Uehara Harbor, Iriomote-jima, Okinawa Prefecture, Japan. This island $\left(24^{\circ} 20^{\prime} \mathrm{N}\right.$, $124^{\circ} 50^{\prime} \mathrm{E}$ ), one of the Yaeyama Group in the Ryukyu Islands, is located in the subtropics and is largely surrounded by coral reefs and mangroves. In April and May of 1998 , the water temperature was $24.5-28.0^{\circ} \mathrm{C}$ and the salinity was $30-32 \%$ at the sea-surface.

Uehara Harbor is surrounded by two long breakwaters, "which prevent surf from entering the harbor. The tidal pattern there is semidiurnal. In April and May, the height of high tides was only moderately different between day and night and differed by $70 \mathrm{~cm}$ between spring tides $(210 \mathrm{~cm})$ and neap tides $(140 \mathrm{~cm})$. The height of low tides differed by $25-50 \mathrm{~cm}$ between day and night; the tide fell to $20-30 \mathrm{~cm}$ at night and to -5 $\mathrm{cm}$ during the day in the spring tides, and to $100 \mathrm{~cm}$ in the morning and $50 \mathrm{~cm}$ in the evening in the neap tides. Afternoon low waters receded further than morning low waters while this study was being carried out.

\section{Invertebrate sampling from bottom and surface waters}

Small subtidal invertebrates were collected using two impeller pumps (SX-150; Terada Pump Co. Ltd., Japan); one pump for sampling the surface water was suspended at a depth of $50 \mathrm{~cm}$ from two floats, and the other pump for sampling the bottom water was fixed at $50 \mathrm{~cm}$ above the bottom (Fig. 1). The substrate at the pumping site was sandy mud. Water was pumped by each device at a flow rate of about $120 \mathrm{l} / \mathrm{min}$. The position of the floating pump fluctuated vertically with the height of the tide. During spring tides, the surface pump was $2 \mathrm{~m}$ above the bottom at low tide, and $4 \mathrm{~m}$ above the bottom at high tide. During neap tides, it 
was $2.5-3 \mathrm{~m}$ above the bottom at low tide, and about $3.5 \mathrm{~m}$ above the bottom at high tide.

The two pumps ran continuously, and invertebrate samples were collected from an attached nylon net (15 $\times 30 \mathrm{~cm} ; 300 \times 500 \mu \mathrm{m}$ in mesh size) every $30 \mathrm{~min}$ $(3,600$ liters)(Fig. 1). Surface and bottom samples were fixed separately with $5 \%(\mathrm{v} / \mathrm{v})$ formalin and stored. Sampling was carried out continuously from 17 April to 11 May, except when the investigations were interrupted for $4 \mathrm{hrs}(0000-0400 \mathrm{~h})$ on 25 April because of a power failure.

\section{Identification of species or higher taxa, and ANOVA test for factors affecting the timing of emergence}

At our laboratory in Okayama, the species (or genera or families, if more precise identification was not possible) were identified under a stereomicroscope (Nishimura 1995; Chihara \& Murano 1997). The abundance of each taxon was plotted every $30 \mathrm{~min}$, in relation to time of day, tidal phase, and lunar phase. The degree of synchrony of each emergence pattern with the day/night, tidal, and lunar cycles was examined by visual inspection. In addition, the period of each pattern was estimated by two statistical methods: autocorrelograms and periodograms (see Oishi \& Saigusa 1999; Saigusa \& Oishi 1998). Furthermore, a two-way ANOVA was applied to determine whether there was any significant difference in abundance between day and night and between surface and bottom.

\section{Collection of bottom substrate during the day}

To investigate which small invertebrates inhabit the substrate beneath the bottom pump, we collected sandy mud from the bottom surface while diving. Substrate was collected from 15 to 25 June 1999, using the same nylon net as shown in Fig. 1. This sampling was carried out at another place (Sonai Harbor, Iriomote-jima) about $10 \mathrm{~km}$ away from Uehara, because the site at Uehara (Fig. 1) was too deep for operations on the seabed.

Sonai Harbor is shallower than Uehara, and the water depth at low tide was at most $2 \mathrm{~m}$, making it easy to access the bottom. This harbor was also surrounded by breakwaters, and the environment and substrate on the seabed were very similar to those at Uehara. Substrate sampling was made at low tide in the daytime. The substrate was flooded with seawater and placed in the laboratory until night. Many invertebrates are attracted to light at night (Saigusa \& Oishi
1998). Small invertebrates were collected from the flooded substrate samples by use of a pipette under a flashlight, and specimens were identified under a stereomicroscope just after fixation.

\section{RESULTS}

The small invertebrates collected from 17 April to 11 May 1998 belonged to 17 orders and comprised 50 or more species (Table 1). Calanoid copepods (Labidocera pavo, Chiridius poppei, and three other species) were the most abundant, representing $81.2 \%$ and $84.8 \%$ of the total number of invertebrates collected in the surface and bottom waters, respectively. The second most abundant group was Longipedia sp. (Harpacticoida), and the third most abundant was decapod larvae. There were 24 taxa (mostly single species), all of them being crustaceans except for one pantopod and one mollusc, for which more than 50 individuals were collected in both surface and bottom waters, and this study examined their emergence patterns.

Chiridius poppei, a calanoid copepod, showed a very clear nocturnal pattern in both surface and bottom waters (Fig. 2; see also Appendix 1). The emergence patterns at both depths were very similar to each other. A large amplitude on the autocorrelogram at a period of $24.0 \mathrm{hrs}$ and a sharp peak at $24 \mathrm{hrs}$ on the periodogram suggest that neither the surface pattern (Fig. 2A) nor the bottom pattern (Fig. 2B) was affected by the tide. However, based on visual inspection, presence at the surface (Fig. 2A) seemed to be somewhat modified by the tide during the latter half of the sampling period.

The emergence patterns of three species of copepods (Acartia fossae, Paracalanus parvus, and Pontella sp.; results of all three lumped together) were also nocturnal, although some specimens were collected in the daytime (Fig. 3). The amplitude of the autocorrelogram and the 24-hr peak on the periodogram were smaller than those of Chiridius poppei (Fig. 2), indicating that emergence is less strongly synchronized with the 24-h day/night cycle than in C. poppei. Tidal influence was not detected. Visual inspection, and the autocorrelogram and periodogram all show that the surface pattern (Fig. 3A) is much the same as the bottom pattern (Fig. 3B).

As shown in Appendix 1, the small subtropical invertebrates included in this study all showed a strong nocturnal emergence, except for Corycaeus sp.; however, the nocturnal patterns varied among groups. 
Table 1. Species composition and the number of the small invertebrates collected by the bottom and surface pumps, respectively. The number of each taxon collected from 17 April to 11 May 1998 is shown by three significant digits.

\begin{tabular}{|c|c|c|c|c|c|c|c|}
\hline \multirow{2}{*}{\multicolumn{2}{|c|}{$\frac{\text { Taxa }}{\text { PyCNOCONInA }}$}} & Bottom & Surface & \multicolumn{2}{|r|}{ Taxa } & Bottom & \multirow[t]{2}{*}{ Surface } \\
\hline & & & & 12 & Stomatopoda & & \\
\hline \multirow[t]{3}{*}{1} & Pantopoda & & & & Alima larvae & 3 & 4 \\
\hline & Propallene longiceps & 454 & 429 & & & & \\
\hline & & & & 13 & Cumacea & & \\
\hline \multicolumn{2}{|c|}{ OSTRACODA } & & & & Nannastacus gibossus & 450 & 1,026 \\
\hline \multirow[t]{2}{*}{2} & Podocopida & & & & Eocuma hilgendorfi & 1 & 0 \\
\hline & Propontocypris pirifera & 11 & 17 & & Cumella sp. & 1 & 1 \\
\hline \multirow[t]{4}{*}{3} & Myodocopida & & & 14 & Isopoda & & \\
\hline & Vargula hilgendorfii & 5,940 & 2,430 & & Haliophasma sp. & 0 & \\
\hline & Xenoleberis yamadai & 12 & 45 & & Paranthura sp. & 0 & 14 \\
\hline & & & & & Cymodoce japonica & 78 & 245 \\
\hline \multicolumn{2}{|c|}{ COPEPODA } & & & & Limnoria lignorum & 351 & 302 \\
\hline \multirow[t]{7}{*}{4} & Calanoida & & & & Gnathia sp. & 215 & 80 \\
\hline & Labidocera pavo & 17,300 & 9,030 & & Excirolana chiltoni & 6 & 1 \\
\hline & Chiridius poppei & 72,750 & 67,890 & & Fam. Munnidae & 23 & 21 \\
\hline & Acartia fossae & & & & Fam. Cymothoidae & 0 & 1 \\
\hline & Paracalanus parvus s.l. & 44,940 & 72,250 & & & & \\
\hline & Pontella sp. & & & 15 & Amphipoda & & \\
\hline & & & & & Pontogeneia sp. & 359 & 399 \\
\hline \multirow[t]{4}{*}{5} & Harpacticoida & & & & Paradexamine barnardi & 10 & 19 \\
\hline & Longipedia sp. & 5,360 & 4,900 & & Ericthonius sp. & 1,910 & 4,330 \\
\hline & Porcellidium sp. & 83 & 72 & & Stenothoe valida & 0 & 2 \\
\hline & & & & & Corophium crassicorne & 0 & 6 \\
\hline \multirow[t]{3}{*}{6} & Poecilostomatoida & & & & Podocerus inconspicuus & 0 & 1 \\
\hline & Corycaeus sp. & 48 & 44 & & Photis reinhandi & 17 & 31 \\
\hline & & & & & Leucothoe nagatai & 6 & 0 \\
\hline \multirow[t]{3}{*}{7} & Caligoida & & & & Synchelidium sp. & 17 & 15 \\
\hline & Lepeophtheirus goniistii & 2 & 5 & & Urothoe sp. & 93 & 57 \\
\hline & Monstrilloida & & & & $\begin{array}{l}\text { Phronima sedentaria } \\
\text { Simorhynchotus antennarius }\end{array}$ & 5 & 3 \\
\hline 8 & Monstrilla sp. & 24 & 17 & & Caprella acutifrons & 1 & 2 \\
\hline \multicolumn{2}{|c|}{ MALACOSTRACA } & & & 16 & Decapoda & & \\
\hline \multirow[t]{3}{*}{9} & Leptostraca & & & & Acetes japonicus & 8 & 66 \\
\hline & Nebalia japanensis & 5 & 0 & & Lucifer hanseni & 488 & 24 \\
\hline & & & & & Saron sp. & 1 & 1 \\
\hline \multirow[t]{4}{*}{10} & Mysidacea & & & & Zoeas (shrimps) & 3,740 & 2,980 \\
\hline & Pseudanchialina inermis & 1342 & & & Glaucothoe larvae & 13 & 9 \\
\hline & Haplostylus indicus & 1,342 & 126 & & Zoeas (crabs) & 718 & 2,213 \\
\hline & & & & & Megalopae & 80 & 95 \\
\hline \multirow[t]{3}{*}{11} & Tanaidacea & & & & & & \\
\hline & $\begin{array}{l}\text { Anatanais normani } \\
\text { Apseudes sp. }\end{array}$ & 745 & 987 & 17 & $\begin{array}{l}\text { Gastropoda } \\
\text { (one species) }\end{array}$ & 8590 & 5630 \\
\hline & & & & & Total & ca. 166,200 & ca. 175,820 \\
\hline
\end{tabular}

Some patterns (Vargula hilgendorfii, Longipedia andamanica, Nannastacus gibossus, two species of mysids, and a small snail) were similar to those in Figs. 2 and 3, showing no influence of, or being only very weakly affected by, the tidal cycle. On the other hand, in Propallene longiceps, Labidocera pavo, tanaidaceans, isopods, amphipods, and decapods, the nocturnal patterns were clearly modified by the tide. One such pattern (shrimp larvae) is shown in Fig. 4. Tide-associated modification of the pattern is not clearly seen in the periodogram, but the peak shift upwards from $24.0 \mathrm{hrs}$ in the autocorrelogram indicates that the emergence pattern was affected by the tide.

A difference in emergence at night between the surface and bottom waters was further seen in some animals (Appendix 1). For example, for Labidocera pavo, two species of mysids, Lucifer hanseni, and Acetes japonicus, many more specimens were collected from the bottom water than from the surface water, and the difference between the two depths was clearly significant. In contrast, zoeas of crabs were more abundant in the surface water than in the bottom water. 

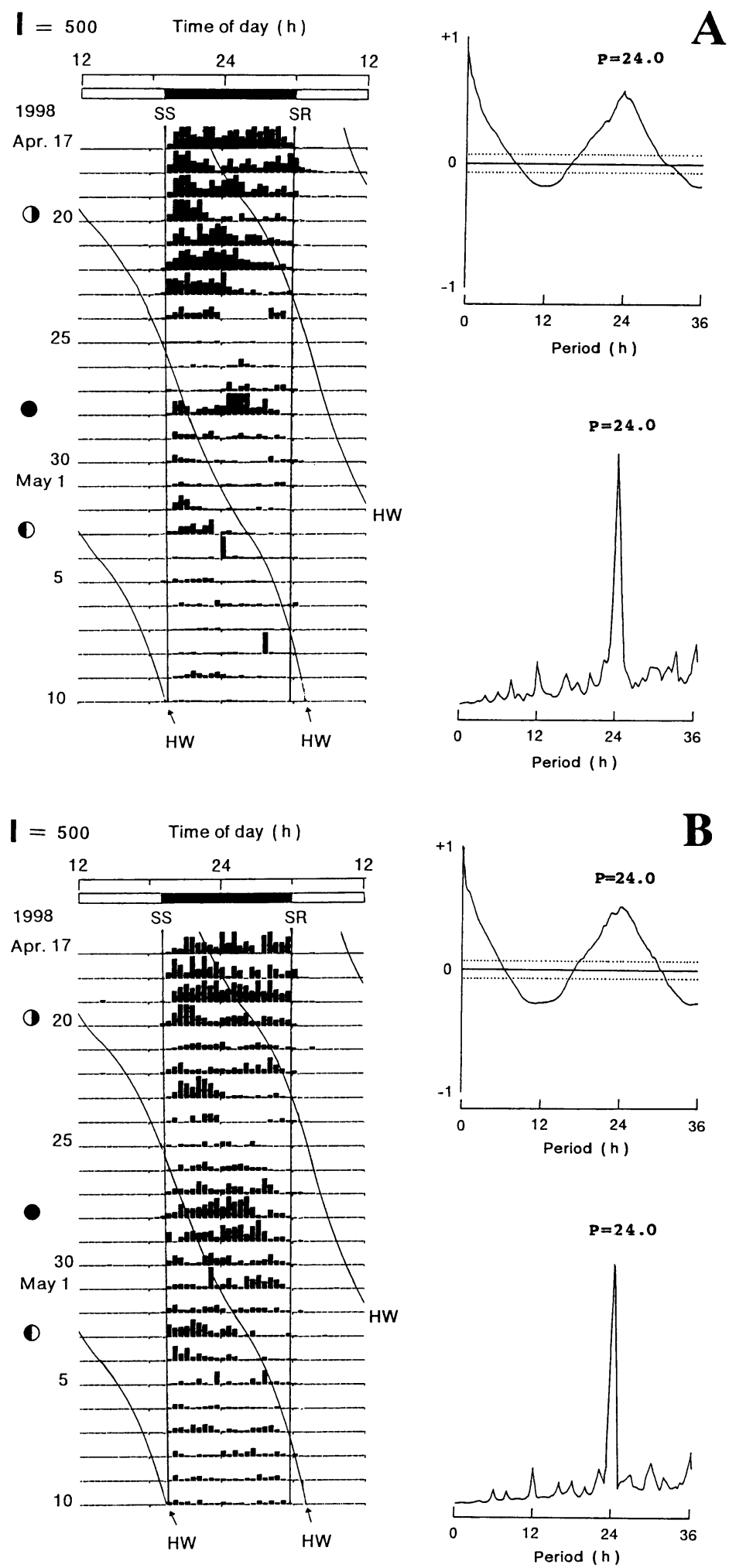

Fig. 2. Emergence patterns of a copepod, Chiridius poppei. Upper panel (A): surface water. Lower panel (B): bottom water. SS and SR are the times of sunset and sunrise, respectively (the solid horizontal bar indicates the period of darkness). HW indicates the times of high tides. Vertical bars represent the number of specimens collected every 30 mins. The vertical bar on top left of each panel shows the scale for the number of the specimens. 0 : new moon. 1 and 1 : the first and last quarters of the moon, respectively. $\mathbf{P}$ represents the period length in each pattern estimated from the autocorrelogram (upper right) and periodogram (lower right). Dotted lines on the autocorrelogram indicate $95 \%$ confidence limits. 

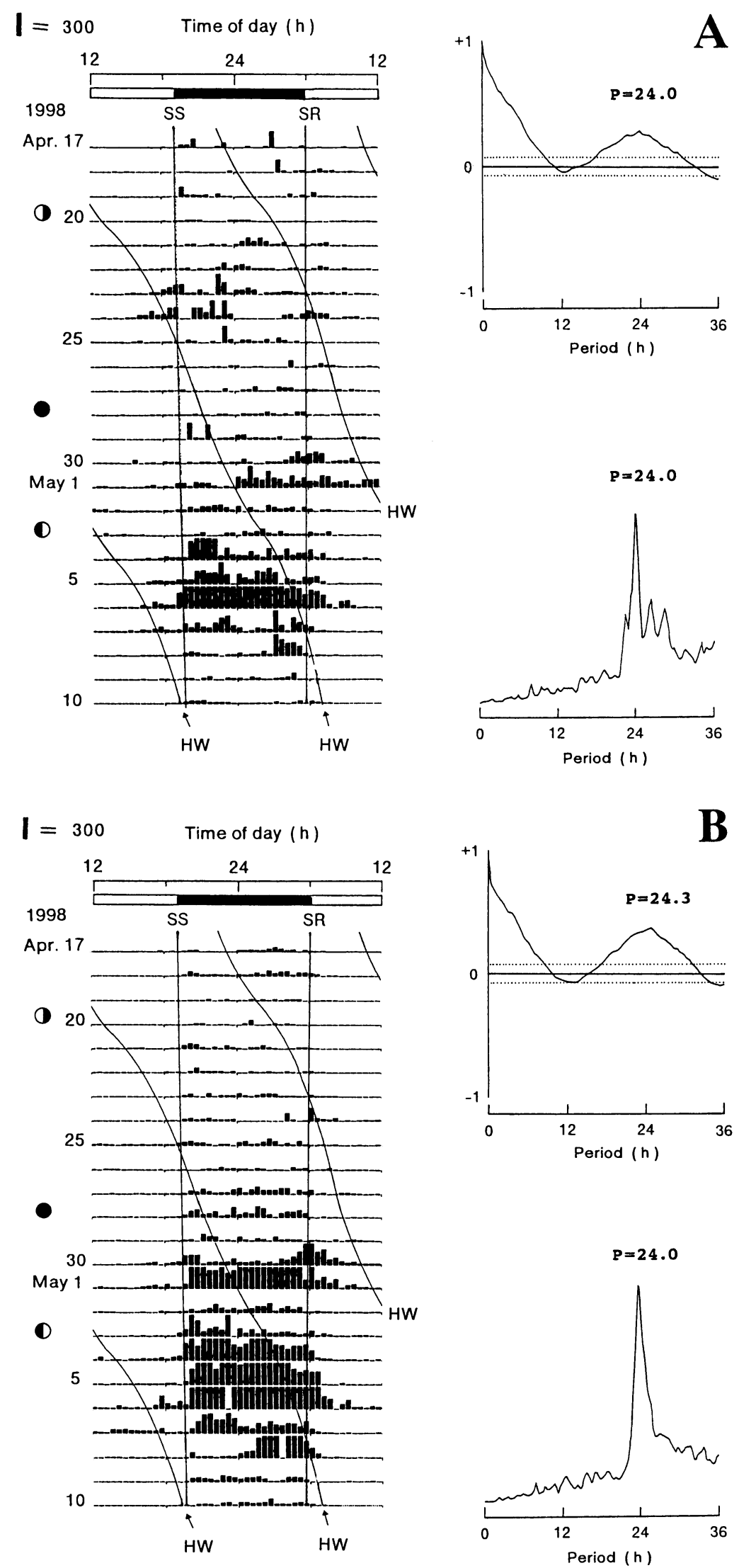

Fig. 3. Nocturnal emergence patterns of three species of copepod (Acartia fossae, Paracalanus parvus, and Pontella sp.). Upper panel (A): surface water. Lower panel (B): bottom water. Symbols as in Fig. 2. 

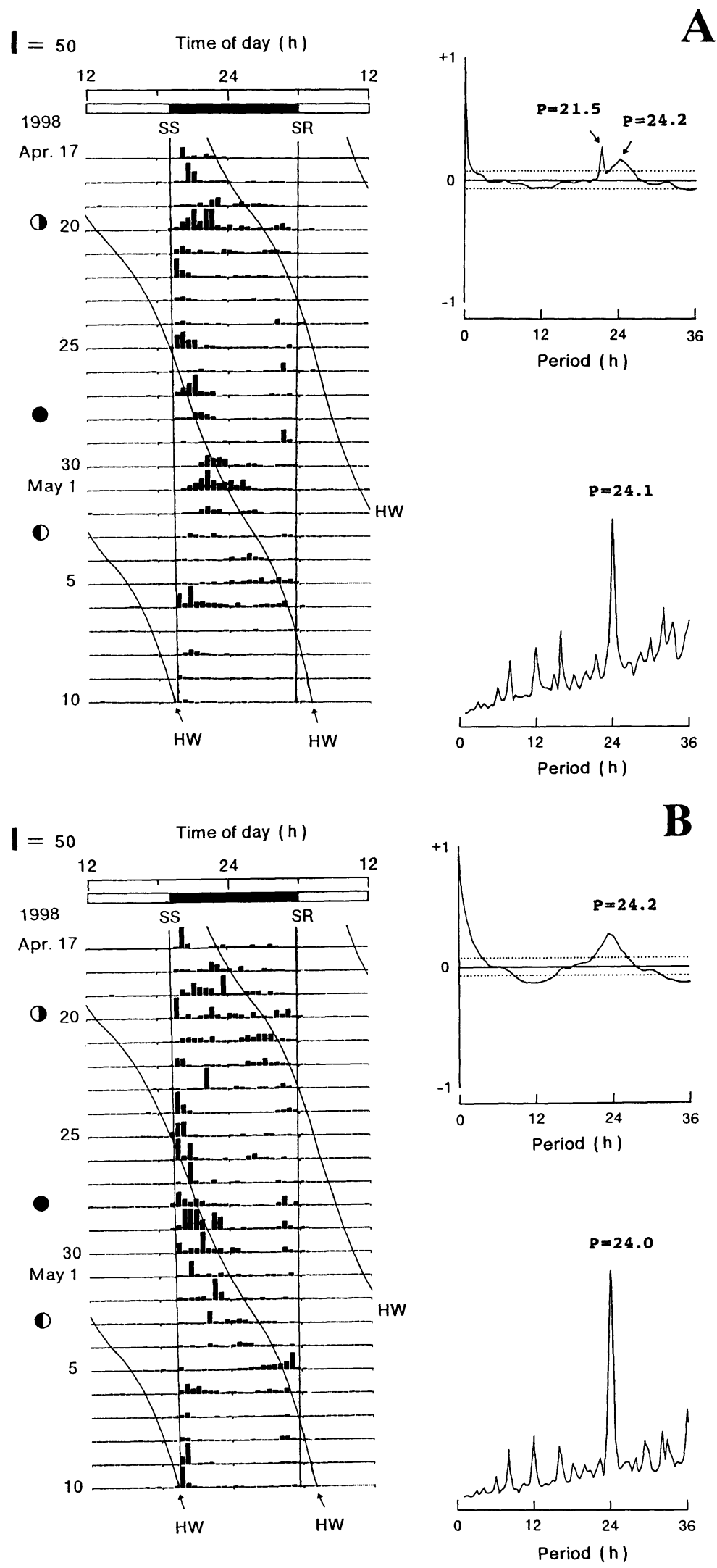

Fig. 4. Nocturnal emergence pattern of zoea larvae of shrimps (Decapoda). Species were not identified. Upper panel (A): surface water. Lower panel (B): bottom water. Symbols as in Fig. 2. 
Invertebrates collected by the pumps were also found in the bottom substrate. The most abundant were Acartia fossae and Chiridius poppei (Calanoida), Apseudes sp. (Tanaidacea), Longipedia sp. and Metis holothuriae (Harpacticoida), and zoea larvae of shrimps comprising several species (Decapoda; species unknown). The next most abundant were Ericthonius sp., Gammarus japonica, and Pontogeneia sp. (Amphipoda), and Nannastacus gibbossus (Cumacea). In the Myodocopida, Vargula hilgendorfii and Cypridina sp. (both are luminescent species) were relatively abundant. In the Isopoda, many Limnoria lignorum were present. On the other hand, Labidocera pavo (Calanoida) and Proparene longiceps (Pantopoda) were very few. Thus, almost all the common taxa from the pump collections summarized in Appendix 1 could also be collected from the substrate at the bottom in the daytime.

\section{DISCUSSION}

The most remarkable feature of the daily rhythms of emergence in the investigated subtropical invertebrates was their very clear nocturnal pattern in both surface and bottom waters (Appendix 1). One explanation for this might be that the animals increase their activity during the day and easily escape from the pump. However, this kind of pump is relatively powerful, of ten sucking in fish and squid if it is not covered by a cage. Furthermore, there is no evidence that all subtropical invertebrates become more active by day than at night.

Another explanation for the nocturnal emergence pattern is that all the species reported here leave the study site (Fig. 1) in the daytime. For example, we may consider a freshwater cladoceran, Daphnia hyalina, which is known to show daily horizontal migration. By day, this species aggregates near the shore, which is densely covered with water plants, and it disperses offshore for grazing at night (Davies 1985). A horizontal migration of marine benthos and zooplankton may occur if hiding places are close by. The benthos and zooplankton at our study site may possibly have moved offshore by day to seek shelter.

If all the species reported here left the study site in the daytime, the number of specimens collected by the two pumps should have decreased greatly by day. For horizontal migration to be possible, however, all the animals must be relatively strong swimmers so that they are not brought back to shore by the rising tide. Indeed, some larger amphipods and isopods may be able to swim against rising tides to some extent, but it is unlikely that almost all invertebrates, including copepods and zoeas, also have the ability to go out and return against the tidal cycle.

The third explanation is that subtropical invertebrates leave the study site and swarm elsewhere in the daytime. Swarming of marine zooplankton is widespread phenomena. For example, Hirota (1990), who studied vertical distribution of a copepod, Oithona davisae, in shallow water in Ariake Bay (Japan), found that the copepods swarm near the surface by day. Tropical copepods (Oithona oculata and Centropages orsinii) form swarms 1-2 $\mathrm{m}$ in diameter over white sand during the day (Hamner \& Carleton 1979). Ueda et al. (1983) reported that several temperate and subtropical species of copepod swarm on or a little above the bottom near the shore, and they speculated that swarming of this type may be a common phenomenon in copepods inhabiting shallow waters. Their report (Ueda et al. 1983) described a disc-shaped swarm of Labidocera pavo that was $10-20 \mathrm{~cm}$ in diameter and located $0.5-1 \mathrm{~m}$ above the flat, sandy bottom.

In our sampling of the bottom substrate at Sonai, the number of Acartia fossae collected was very different among substrate samples, which suggests that this species is distributed just above the bottom in a patchy manner by day. On the other hand, very few specimens of Labidocera pavo were collected from the substrate. At Sonai, the substrate was collected within $10 \mathrm{~m}$ of the pier. If L. pavo swarms, it might occur somewhat deeper than the sampling site. Nevertheless, nocturnal patterns of emergence cannot be fully explained in terms of swarming in the daytime. Furthermore, there are many species for which swarming is not known to occur (e.g. most benthic animals).

The fourth explanation is related to the daily activity rhythm of subtropical invertebrates. Since almost all the taxa were collected from the bottom substrate by day, they should be present in the harbor not only at night but also by day. If so, some zooplankton will be found just above the bottom in the daytime regardless of whether swarming occurs or not, and benthic animals will be hiding in the substrate by day. This behavior would prevent both the zooplankton and benthos from being collected even by the bottom pump in the daytime, whereas when they disperse into the water column at night they are collected by both the surface and bottom pumps.

As shown in Appendix 1, the degree of nocturnal emergence was different among taxa. For example, the nocturnal tendencies of Propallene longiceps, 
Longipedia sp., Ericthonius sp., and shrimp larvae were very strong. In contrast, those of Porcellidium sp., $L u$ cifer hanseni, and a gastropod (one species) were much weaker. For groups showing very clear nocturnal emergence, all specimens must be strongly confined to the bottom substrate by day. On the other hand, for animals showing less strong nocturnal emergence, a fraction of the population may disperse into the water column above the substrate in the daytime.

Daily vertical migration is one of the most characteristic features of behavior in marine invertebrates (Lalli \& Parsons 1993). Each species has its own preferred range of depth by day and by night (e.g. Herman 1963; Zaret \& Sufferen 1976; Rimmer \& Phillips 1979; Simard et al. 1985). As indicated in this study, daily vertical migration can occur in the shallow subtidal zone. In this case, however, the pattern of migration is clearly modified: almost all the animals reside on the substrate or hide within it during the day, and they swim or disperse into the water column at night. The differences in abundance between the surface and bottom (Appendix 1) show that each species has a preferred zone for swimming or dispersing. Such behavior should be called 'daily emergence/dispersal' rather than 'daily vertical migration'.

Small invertebrates inhabiting shallow subtidal zones near the shore may be divided into two groups according to their lifestyle: zooplankton and benthos (e.g. Lalli \& Parsons 1993). Zooplankton are defined as organisms that spend almost all of their time in the water column, and benthos as dwellers in the bottom substrate or on seaweeds, though they sometimes may swim in the water column. In our study, however, daily swimming or dispersing activity was demonstrated for a wide range of animals; as a result, the distinction between 'benthos' and 'plankton' has become blurred for those small subtropical marine invertebrates of the subtidal zone.

Acknowledgments. Y. Katsube, A. Ikumoto, and H. Yamada helped us with daytime sampling. This work was supported by a Grant-in-Aid for Science Research (C) (2) to M.S. (No. 10836014: Natural History) from the Ministry of Education, Science, Sports and Culture, Japan. It was also supported by a Narishige Zoological Science Award to M.S. in 1997, and by a Sasakawa Scientific Research Grant (Japan Science Society; Marine Biology) to K.O. in 1998. We thank the staff of the Tropical Biosphere Research Center (Iriomote Laboratory) of the University of the Ryukyus for use of their facilities during this study. Dr. S. Hiruta identified the two luminescent species of Myodocopida.

\section{REFERENCES}

Bollens, S. M., B. W. Frost and J. R. Cordell 1994 Chemical, mechanical and visual cues in the vertical migration behavior of the marine planktonic copepod Acartia hudsonica. Journal of Plankton Research, 16: 555-564.

Chihara, M. and M. Murano (eds.) 1997 An Illustrated Guide to Marine Plankton in Japan. Tokai University Press, Tokyo, 1574 pp. (in Japanese).

Davies, J. 1985 Evidence for a diurnal horizontal migration in Daphnia hyalina lacustris Sars. Hydrobiologia, 120: 103-105.

Forward, R. B. Jr. 1988 Diel vertical migration: zooplankton photobiology and behaviour. Oceanography and Marine Biology, an Annual Review, 26: 361-393.

Gauld, D. T. 1953 Diurnal variations in the grazing of planktonic copepods. Journal of the Marine Biological Association of the United Kingdom, 31: 461-474.

Hamner, W. M. and J. H. Carleton 1979 Copepod swarms: attributes and role in coral reef ecosystems. Limnology and Oceanography, 24: 1-14.

Herman, S. S. 1963 Vertical migration of the opossum shrimp, Neomysis americana Smith. Limnology and Oceanography, 8: 228-238.

Hirota, R. 1990 Microdistribution of the marine copepod Oithona davisae in the shallow waters of Ariake-kai mud flats, Japan. Marine Biology, 105: 307-312.

Lalli, C. M. and T. R. Parsons 1993 Biological Oceanography: An Introduction. Butterworth-Heinemann Ltd, Oxford, $301 \mathrm{pp}$.

Nishimura, S. (ed.) 1995 Guide to Seashore Animals of Japan with Color Pictures and Keys (Vol. II). Hoikusha, Osaka, 663 pp. (in Japanese).

Oishi, K. and M. Saigusa 1999 Rhythmic patterns of abundance in small sublittoral crustaceans: variety in the synchrony with day/night and tidal cycles. Marine Biology, 133: 237-247.

Rimmer, D. W. and B. F. Phillips 1979 Diurnal migration and vertical distribution of phyllosoma larvae of the western rock lobster Panulirus cygnus. Marine Biology, 54: 109-124.

Saigusa, M. and K. Oishi 1998 Patterns of emergence in marine invertebrates: on the influence of a field light. Benthos Research, 53: 95-104.

Simard, Y., G. Lacroix and L. Legendre 1985 In situ twilight grazing rhythm during diel vertical migrations of a scattering layer of Calanus finmarchicus. Limnology and Oceanography, 30: 598-606. 
Ueda, H., A. Kuwahara, M. Tanaka and M. Azeta 1983 Underwater observations on copepod swarms in temperate and subtropical waters. Marine Ecology Progress Series, 11: 165-171.
Zaret, T. M. and J. S. Suffern 1976 Vertical migration in zooplankton as a predator avoidance mechanism. Limnology and Oceanography, 21: 804-813.

Appendix 1. Two-way ANOVA of emergence. The environmental factors have two levels: day/night and surface/bottom. df : degrees of freedom; MS: mean square; $F: F$ value. $\quad$ * = significant ; NS = not significant.

\begin{tabular}{|c|c|c|c|c|c|}
\hline Animals & & $\mathrm{df}$ & MS & $F$ & \\
\hline \multirow[t]{5}{*}{ Propallene longiceps } & Day/night & 1 & 6256.51 & 94.92 & ${ }^{*} P<0.001$ \\
\hline & Surface/bottom & 1 & 6.51 & 0.10 & NS $P>0.05$ \\
\hline & Interaction & 1 & 14.26 & 0.22 & NS $P>0.05$ \\
\hline & Residual & 92 & 65.91 & & \\
\hline & Total & 95 & & & \\
\hline \multirow[t]{5}{*}{ Vargula hilgendorfii } & Day/night & 1 & 609609.38 & 13.45 & ${ }^{*} P<0.001$ \\
\hline & Surface/bottom & 1 & 128920.04 & 2.84 & NS $P>0.05$ \\
\hline & Interaction & 1 & 104676.04 & 2.31 & NS $P>0.05$ \\
\hline & Residual & 92 & 45325.53 & & \\
\hline & Total & 95 & & & \\
\hline \multirow[t]{5}{*}{ Xenoleberis yamadai } & Day/night & 1 & 27.09 & 29.43 & ${ }^{*} P<0.001$ \\
\hline & Surface/bottom & 1 & 11.34 & 12.32 & ${ }^{*} P<0.001$ \\
\hline & Interaction & 1 & 10.01 & 10.87 & ${ }^{*} P<0.01$ \\
\hline & Residual & 92 & 0.92 & & \\
\hline & Total & 95 & & & \\
\hline \multirow[t]{5}{*}{ Labidocera pavo } & Day/night & 1 & 5777600.01 & 75.95 & ${ }^{*} P<0.001$ \\
\hline & Surface/bottom & 1 & 712598.34 & 9.37 & ${ }^{*} P<0.01$ \\
\hline & Interaction & 1 & 509396.34 & 6.70 & ${ }^{*} P<0.05$ \\
\hline & Residual & 92 & 76068.02 & & \\
\hline & Total & 95 & & & \\
\hline \multirow[t]{5}{*}{ Chiridius poppei } & Day/night & 1 & 189335028.76 & 68.14 & ${ }^{*} P<0.001$ \\
\hline & Surface/bottom & 1 & 245936.26 & 0.09 & NS $P>0.05$ \\
\hline & Interaction & 1 & 351747.09 & 0.13 & NS $P>0.05$ \\
\hline & Residual & 92 & 2778725.84 & & \\
\hline & Total & 95 & & & \\
\hline Acartia fossae & Day/night & 1 & 65356501.04 & 12.79 & ${ }^{*} P<0.001$ \\
\hline Paracalanus parvus s.l. & Surface/bottom & 1 & 7769126.04 & 1.52 & NS $P>0.05$ \\
\hline \multirow{3}{*}{ Pontella sp. } & Interaction & 1 & 7793040.67 & 1.53 & NS $P>0.05$ \\
\hline & Residual & 92 & 5109083.98 & & \\
\hline & Total & 95 & & & \\
\hline \multirow[t]{5}{*}{ Longipedia sp. } & Day/night & 1 & 880708.59 & 112.23 & ${ }^{*} P<0.001$ \\
\hline & Surface/bottom & 1 & 2252.34 & 0.29 & NS $P>0.05$ \\
\hline & Interaction & 1 & 5969.26 & 0.76 & NS $P>0.05$ \\
\hline & Residual & 92 & 7847.61 & & \\
\hline & Total & 95 & & & \\
\hline \multirow[t]{5}{*}{ Porcellidium sp. } & Day/night & 1 & 40.04 & 7.75 & ${ }^{*} P<0.01$ \\
\hline & Surface/bottom & 1 & 0.38 & 0.07 & NS $P>0.05$ \\
\hline & Interaction & 1 & 0.38 & 0.07 & NS $P>0.05$ \\
\hline & Residual & 92 & 5.16 & & \\
\hline & Total & 95 & & & \\
\hline \multirow[t]{5}{*}{ Corycaeus sp. } & Day/night & 1 & 12.04 & 1.02 & NS $P>0.05$ \\
\hline & Surface/bottom & 1 & 0.17 & 0.01 & NS $P>0.05$ \\
\hline & Interaction & 1 & 3.38 & 0.29 & NS $P>0.05$ \\
\hline & Residual & 92 & 11.81 & & \\
\hline & Total & 95 & & & \\
\hline
\end{tabular}




\begin{tabular}{|c|c|c|c|c|c|}
\hline Animals & & $\mathrm{df}$ & MS & $F$ & \\
\hline $\begin{array}{l}\text { Pseudanchialina inermis } \\
\text { Haplostylus indicus }\end{array}$ & $\begin{array}{l}\text { Day/night } \\
\text { Surface/bottom } \\
\text { Interaction } \\
\text { Residual } \\
\text { Total }\end{array}$ & $\begin{array}{r}1 \\
1 \\
1 \\
92 \\
95\end{array}$ & $\begin{array}{r}15200.67 \\
15402.67 \\
11094.00 \\
317.29\end{array}$ & $\begin{array}{l}47.91 \\
48.54 \\
34.97\end{array}$ & $\begin{array}{l}{ }^{*} \quad P<0.001 \\
{ }^{*} \quad P<0.001 \\
{ }^{*} \quad P<0.001\end{array}$ \\
\hline $\begin{array}{l}\text { Anatanais normani } \\
\text { Apseudes sp. }\end{array}$ & $\begin{array}{l}\text { Day/night } \\
\text { Surface/bottom } \\
\text { Interaction } \\
\text { Residual } \\
\text { Total }\end{array}$ & $\begin{array}{r}1 \\
1 \\
1 \\
92 \\
95\end{array}$ & $\begin{array}{r}21901.04 \\
610.04 \\
726.00 \\
342.33\end{array}$ & $\begin{array}{r}63.98 \\
1.78 \\
2.12\end{array}$ & $\begin{array}{rl}* & P<0.001 \\
\text { NS } & P>0.05 \\
\text { NS } & P>0.05\end{array}$ \\
\hline Nannastacus gibossus & $\begin{array}{l}\text { Day/night } \\
\text { Surface/bottom } \\
\text { Interaction } \\
\text { Residual } \\
\text { Total }\end{array}$ & $\begin{array}{r}1 \\
1 \\
1 \\
92 \\
95\end{array}$ & $\begin{array}{r}15759.38 \\
4347.04 \\
4187.04 \\
532.39\end{array}$ & $\begin{array}{r}29.60 \\
8.17 \\
7.86\end{array}$ & $\begin{array}{ll}{ }^{*} & P<0.001 \\
{ }^{*} & P<0.01 \\
{ }^{*} & P<0.01\end{array}$ \\
\hline Cymodoce japonica & $\begin{array}{l}\text { Day/night } \\
\text { Surface/bottom } \\
\text { Interaction } \\
\text { Residual } \\
\text { Total }\end{array}$ & $\begin{array}{r}1 \\
1 \\
1 \\
92 \\
95\end{array}$ & $\begin{array}{r}1211.26 \\
742.59 \\
508.76 \\
103.16\end{array}$ & $\begin{array}{r}11.74 \\
7.20 \\
4.93\end{array}$ & $\begin{array}{ll}{ }^{*} & P<0.001 \\
{ }^{*} & P<0.01 \\
{ }^{*} & P<0.05\end{array}$ \\
\hline Limnoria lignorum & $\begin{array}{l}\text { Day/night } \\
\text { Surface/bottom } \\
\text { Interaction } \\
\text { Residual } \\
\text { Total }\end{array}$ & $\begin{array}{r}1 \\
1 \\
1 \\
92 \\
95\end{array}$ & $\begin{array}{r}4360.51 \\
25.01 \\
31.51 \\
8616.21\end{array}$ & $\begin{array}{r}46.56 \\
0.27 \\
0.33\end{array}$ & $\begin{array}{rl}* & P<0.001 \\
\mathrm{NS} & P>0.05 \\
\mathrm{NS} & P>0.05\end{array}$ \\
\hline Gnathia sp. & $\begin{array}{l}\text { Day/night } \\
\text { Surface/bottom } \\
\text { Interaction } \\
\text { Residual } \\
\text { Total }\end{array}$ & $\begin{array}{r}1 \\
1 \\
1 \\
92 \\
95\end{array}$ & $\begin{array}{r}625.26 \\
189.84 \\
216.01 \\
14.18\end{array}$ & $\begin{array}{l}44.10 \\
13.39 \\
15.45\end{array}$ & $\begin{array}{ll}{ }^{*} & P<0.001 \\
{ }^{*} & P<0.001 \\
{ }^{*} & P<0.001\end{array}$ \\
\hline Pontogeneia sp. & $\begin{array}{l}\text { Day/night } \\
\text { Surface/bottom } \\
\text { Interaction } \\
\text { Residual } \\
\text { Total }\end{array}$ & $\begin{array}{r}1 \\
1 \\
1 \\
92 \\
95\end{array}$ & $\begin{array}{r}4320.17 \\
16.67 \\
12.04 \\
248.70\end{array}$ & $\begin{array}{r}17.37 \\
0.07 \\
0.05\end{array}$ & $\begin{array}{rl}* & P<0.001 \\
\text { NS } & P>0.05 \\
\text { NS } & P>0.05\end{array}$ \\
\hline Ericthonius sp. & $\begin{array}{l}\text { Day/night } \\
\text { Surface/bottom } \\
\text { Interaction } \\
\text { Residual } \\
\text { Total }\end{array}$ & $\begin{array}{r}1 \\
1 \\
1 \\
92 \\
95\end{array}$ & $\begin{array}{r}305214.26 \\
60651.76 \\
63499.59 \\
2833.43\end{array}$ & $\begin{array}{r}107.72 \\
21.41 \\
22.41\end{array}$ & $\begin{array}{l}{ }^{*} P<0.001 \\
{ }^{*} P<0.001 \\
{ }^{*} P<0.001\end{array}$ \\
\hline Urothoe sp. & $\begin{array}{l}\text { Day/night } \\
\text { Surface/bottom } \\
\text { Interaction } \\
\text { Residual } \\
\text { Total }\end{array}$ & $\begin{array}{r}1 \\
1 \\
1 \\
92 \\
95\end{array}$ & $\begin{array}{r}155.04 \\
13.50 \\
32.67 \\
4.72\end{array}$ & $\begin{array}{r}32.83 \\
2.86 \\
6.92\end{array}$ & $\begin{array}{rl}* & P<0.001 \\
\mathrm{NS} & P>0.05 \\
* & P<0.05\end{array}$ \\
\hline Acetes japonicus & $\begin{array}{l}\text { Day/night } \\
\text { Surface/bottom } \\
\text { Interaction } \\
\text { Residual } \\
\text { Total }\end{array}$ & $\begin{array}{r}1 \\
1 \\
1 \\
92 \\
95\end{array}$ & $\begin{array}{r}40.04 \\
35.04 \\
35.04 \\
2.27\end{array}$ & $\begin{array}{l}17.64 \\
15.44 \\
15.44\end{array}$ & $\begin{array}{l}{ }^{*} \quad P<0.001 \\
{ }^{*} P<0.001 \\
{ }^{*} P<0.001\end{array}$ \\
\hline
\end{tabular}


Saigusa \& Oishi

\begin{tabular}{|c|c|c|c|c|c|}
\hline Animals & & $\mathrm{df}$ & MS & $F$ & \\
\hline Lucifer hanseni & $\begin{array}{l}\text { Day/night } \\
\text { Surface/bottom } \\
\text { Interaction } \\
\text { Residual } \\
\text { Total }\end{array}$ & $\begin{array}{r}1 \\
1 \\
1 \\
92 \\
95\end{array}$ & $\begin{array}{r}2646.00 \\
2204.17 \\
2090.67 \\
444.61\end{array}$ & $\begin{array}{l}5.95 \\
4.96 \\
4.70\end{array}$ & $\begin{array}{l}{ }^{*} \quad P<0.05 \\
{ }^{*} \quad P<0.05 \\
{ }^{*} \quad P<0.05\end{array}$ \\
\hline Zoeas (shrimps) & $\begin{array}{l}\text { Day/night } \\
\text { Surface/bottom } \\
\text { Interaction } \\
\text { Residual } \\
\text { Total }\end{array}$ & $\begin{array}{r}1 \\
1 \\
1 \\
92 \\
95\end{array}$ & $\begin{array}{r}435108.01 \\
5937.76 \\
6288.84 \\
4227.72\end{array}$ & $\begin{array}{r}102.92 \\
1.40 \\
1.49\end{array}$ & $\begin{array}{rl}* & P<0.001 \\
\mathrm{NS} & P>0.05 \\
\mathrm{NS} & P>0.05\end{array}$ \\
\hline Zoeas (crabs) & $\begin{array}{l}\text { Day/night } \\
\text { Surface/bottom } \\
\text { Interaction } \\
\text { Residual } \\
\text { Total }\end{array}$ & $\begin{array}{r}1 \\
1 \\
1 \\
92 \\
95\end{array}$ & $\begin{array}{r}82075.51 \\
23281.51 \\
22785.84 \\
4397.36\end{array}$ & $\begin{array}{r}18.66 \\
5.29 \\
5.18\end{array}$ & $\begin{array}{ll}{ }^{*} & P<0.001 \\
{ }^{*} & P<0.05 \\
{ }^{*} & P<0.05\end{array}$ \\
\hline Megalopae & $\begin{array}{l}\text { Day/night } \\
\text { Surface/bottom } \\
\text { Interaction } \\
\text { Residual } \\
\text { Total }\end{array}$ & $\begin{array}{r}1 \\
1 \\
1 \\
92 \\
95\end{array}$ & $\begin{array}{r}168.01 \\
2.34 \\
1.26 \\
9.26\end{array}$ & $\begin{array}{r}18.13 \\
0.25 \\
0.14\end{array}$ & $\begin{array}{rl}* & P<0.001 \\
\mathrm{NS} & P>0.05 \\
\mathrm{NS} & P>0.05\end{array}$ \\
\hline $\begin{array}{l}\text { Gastropoda } \\
\text { (one species) }\end{array}$ & $\begin{array}{l}\text { Day/night } \\
\text { Surface/bottom } \\
\text { Interaction } \\
\text { Residual } \\
\text { Total }\end{array}$ & $\begin{array}{r}1 \\
1 \\
1 \\
92 \\
95\end{array}$ & $\begin{array}{r}1928367.04 \\
91266.67 \\
98945.04 \\
251511.46\end{array}$ & $\begin{array}{l}7.67 \\
0.36 \\
0.39\end{array}$ & $\begin{array}{rl}* & P<0.01 \\
\mathrm{NS} & P>0.05 \\
\mathrm{NS} & P>0.05\end{array}$ \\
\hline
\end{tabular}

